\title{
The perceived self-efficacy of classroom teachers and preschool teachers for teaching with tablets
}

\author{
Mustafa Bektas $^{1 \mathrm{a}}$ \\ ${ }^{1}$ Sakarya Universty, Faculty of Education, Elementary Education Department, Hendek/Sakarya \\ 54300, Turkey
}

\begin{abstract}
The purpose of this study was to identify the perceived selfefficacy of classroom teachers and preschool teachers for teaching with tablets. The data were collected using the Perceived Self-Efficacy for Teaching with Tablets Scale, which was developed by the researcher. The study used convenience sampling, a type of purposive sampling. The sample was comprised of 171 teachers. In addition to developing the scale, the researcher attempted to reveal whether branch and gender led to a significant difference in perceived self-efficacy for teaching with tablets. Male teachers had higher perceived self-efficacy for teaching with tablets. However, branch was not a statistically significant factor.
\end{abstract}

Keywords: classroom teachers; preschool teachers; teaching with tablets; self-efficacy

\section{Introduction}

Thanks to advances in information technologies, modern societies are characterized by rapid information growth. This, in turn, influences human beings and organizations.

In addition to many learning and teaching methods and techniques, today's teachers use a number of teaching technologies, developed by educational sciences, in learning environments. One of the most commonly used technologies is tablet computers. Research has stressed that the use of tablets can significantly increase the effectiveness of learning and teaching activities.

A tablet is not only a laptop computer that allows users to use a stylus pen to directly access the screen, it also has mouse and keyboard inputs. Thus, tablets can provide an effective platform for drawing and writing activities and can also be used for lecturing [8].

Tablets are becoming more and more common in Turkey, and it is likely that many Turkish students, teachers and parents will soon become familiar with them thanks to the

a Corresponding author: mbektas@sakarya.edu.tr

(C) The Authors, published by EDP Sciences. This is an open access article distributed under the terms of the Creative Commons Attribution License 4.0 (http://creativecommons.org/licenses/by/4.0/). 
Movement to Increase Opportunities and Technology (the FATIH Project), which is still ongoing. The project aims to equip all classrooms for students in fifth grade or higher across the nation with interactive boards and to provide them with tablets [5].

Tablets are practical learning and teaching tools since they are easy to carry and can host many applications. Research suggests that most Turkish teachers are already using them to access e-school applications and e-books. Still, they are not used commonly as an effective learning and teaching tool. Similarly, students use them mostly for recreational purposes [10].

As primary practitioners, teachers are ultimately responsible for the implementation of the FATIH project, and they play a pivotal role in the process [3]. Several studies have been carried out to measure the perceived self-efficacy of students for tablets [9]. The positive effects of tablets on the learning and teaching process can be increased when teachers have higher perceived self-efficacy for using them to teach.

Bandura [2] describes self-efficacy as people's assessment of their ability to organize and execute procedures for a planned action. Perceived self-efficacy concerns competence and ability, or in simpler terms, the statement "I can do it." Teachers need to have high perceived self-efficacy for teaching with tablets so that they can effectively use them for educational purposes. Thus, a scale needs to be developed to measure their perceived selfefficacy and to reveal the relevant variables.

The purpose of this study was to identify the perceived self-efficacy of classroom teachers and preschool teachers for teaching with tablets. Accordingly, it posed the following questions:

1. Is there a difference between classroom teachers' and preschool teachers' perceived self-efficacy for teaching with tablets?

2. Does teachers' perceived self-efficacy for teaching with tablets vary by gender?

\section{Method}

\subsection{Research model}

Cross-sectional survey is a research model in which variables are measured once to determine whether they differ depending on other variables [7]. Since it was compatible with the purpose, a cross-sectional model was used in this study.

\subsection{Sample}

The study used convenience sampling, a type of purposive sampling. The sample was comprised of 171 ( 86 females and 85 males) classroom teachers and preschool teachers in National Education Directorate schools in Sakarya, Turkey during the 2014-2015 academic year.

\subsection{Data collection instrument}

The data were collected using the Perceived Self-Efficacy for Teaching with Tablets Scale, which was developed by the researcher. Before the scale was developed, the researcher reviewed the relevant research and scales in the literature [1, 4 and 11]. Then, an item pool was created. The content validity and face validity of the item pool, which contained 30 items, were tested by two specialists. Half of the items were excluded, and 15 remained. Two forms were prepared for the scale, one for specialists and the other for teachers. The former was submitted to 3 faculty members from the department of elementary education 
and 3 faculty members from the department of computer education and instructional technologies teaching. The latter form was submitted to 18 classroom teachers and 5 preschool teachers. The scale was revised in accordance with their recommendations, and its final version had 8 items. It is a five-point scale, using the ratings: "Strongly agree (5 points)", "Agree (4 points)", "Neutral (3 points)", "Disagree (2 points)" and "Strongly Disagree (1 point)." The maximum and minimum possible scores are 40 and 8 , respectively.

An exploratory factor analysis was carried out to test the construct validity of the scale. Great care was taken to ensure that the eigenvalues of the items would be 1 , that the load values of the items would be at least 0.30 , that the items would be grouped under a single factor, and that items to be grouped under two factors would have a difference of at least 0.10. First, the Kaiser-Meyer-Olkin (KMO) test was performed to assess the sufficiency of the sample. The KMO value was 0.934 , which indicated that a factor analysis could be conducted on the data since the value was higher than 0.80 [6]. Then, Bartlett's test of sphericity was performed. Since the data were significantly different $(\chi 2=1534.055$, $\mathrm{p}=0.000$ ), they were appropriate for factor analysis [6]. The subsequent validity analyses showed that the scale had a single-factor structure.

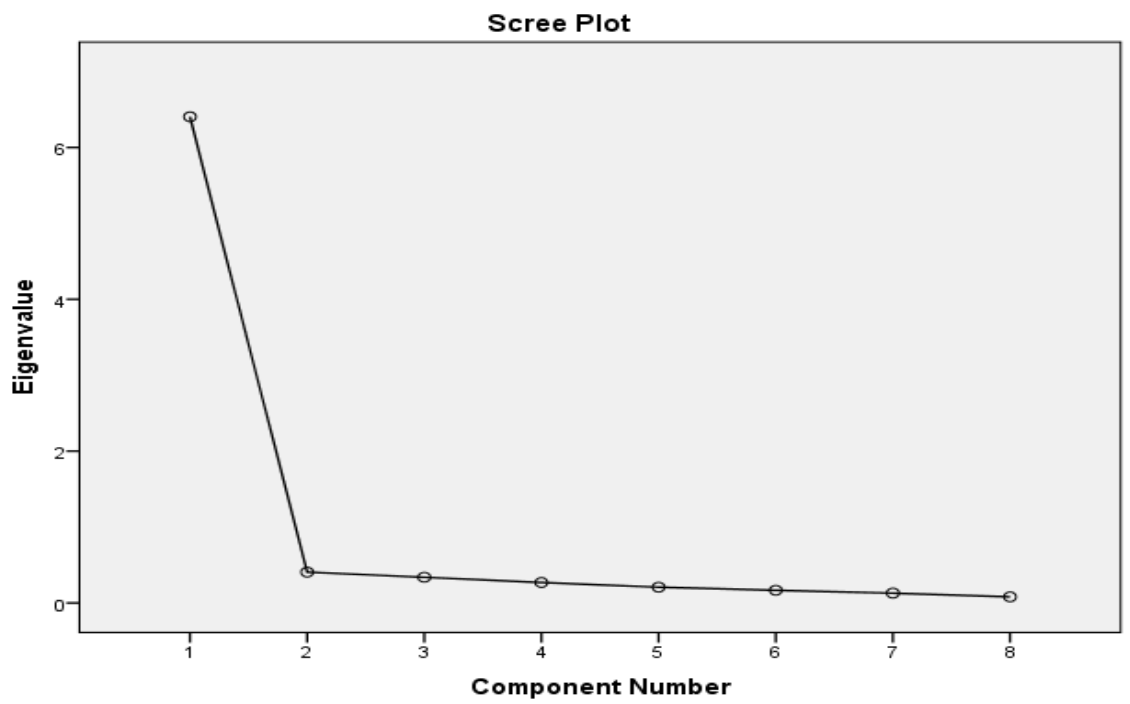

Fig. 1. The scree-plot

As can be concluded from the scree plot, the factor analysis showed that the scale had a single-factor structure when the eigenvalue was 1 . 
Table 1. The results of the factor analysis for the Perceived Self-Efficacy for Teaching with Tablets Scale

\begin{tabular}{lcc}
\hline Item & Common Factor Variance & Factor Load Values \\
\hline i1 & 0.743 & 0.862 \\
i2 & 0.804 & 0.897 \\
i3 & 0.825 & 0.908 \\
i4 & 0.812 & 0.901 \\
i5 & 0.833 & 0.913 \\
i6 & 0.833 & 0.912 \\
i7 & 0.851 & 0.922 \\
i8 & 0.703 & 0.839 \\
Eigenvalue (Total=6.40) & & \\
Variance Accounted for \%=80.05 & & \\
\hline
\end{tabular}

The Perceived Self-Efficacy for Teaching with Tablets Scale had an eight-item and single-factor structure (Table 1). The total eigenvalue of the scale was 6.40 , and the total variance accounted for was $80.5 \%$. The factor load values of the items varied from 0.83 to 0.92. As for reliability, its Cronbach's alpha coefficient was 0.96 .

\subsection{Data Analysis}

An independent samples t-test was performed to determine whether branch and gender led to difference in perceived self-efficacy for teaching with tablets.

\section{Findings}

Table 2 presents the results of the t-test on the perceived self-efficacy of classroom teachers and preschool teachers for teaching with tablets.

Table 2. The results of the t-test on the difference between the classroom teachers and preschool teachers in their perceived self- efficacy for teaching with tablets

\begin{tabular}{lcccccc}
\hline Branch & N & $\bar{x}$ & ss & Sd & t & P \\
\hline Classroom Teaching & 150 & 29.75 & 6.328 & & & \\
Preschool Teaching & 22 & 28.64 & 5.491 & & & \\
\hline
\end{tabular}

There was no statistically significant difference between the classroom teachers' and preschool teachers' perceived self-efficacy for teaching with tablets $(t=0.781, p>0.05)$ (Table 2). Therefore, branch was ignored when the participants were compared by gender. Table 3 presents the gender-based results of the t-test on perceived self-efficacy of the participants for teaching with tablets. 
Table 3. The gender-based results of the t-test on self-efficacy of the participants for teaching with tablets

\begin{tabular}{lcccccc}
\hline Gender & $\mathbf{N}$ & $\bar{x}$ & ss & Sd & t & $\mathbf{P}$ \\
\hline Female & 86 & 28.63 & 6.237 & 169 & -2.061 & $0.041^{*}$ \\
Male & 85 & 30.58 & 6.126 & & & \\
\hline
\end{tabular}

There was a statistically significant difference between female and male teachers' perceived self-efficacy for teaching with tablets $(\mathrm{t}=-2.061, \mathrm{p}<0.05)$ (Table 3). Male teachers $(\bar{x}=30.58)$ had significantly higher perceived self-efficacy for teaching with tablets than female teachers $(\vec{x}=28.63)$.

\section{Discussion}

First, a valid and reliable scale was developed, namely the Perceived Self-Efficacy for Teaching with Tablets Scale. The findings are discussed below with recommendations.

There is no statistically significant difference between the classroom teachers' and preschool teachers' perceived self-efficacy for teaching with tablets. This finding suggests that perceived self-efficacy for teaching with tablets does not vary by branch.

Male teachers have higher perceived self-efficacy for teaching with tablets. Similarly, Berkant [4] found that male teacher candidates have significantly higher perceived selfefficacy for using computers. Lack of experience in using computers causes users to have lower perceived self-efficacy for computers [1]. This finding is supported in the literature.

The Perceived Self-Efficacy for Teaching with Tablets Scale could be used in research on a variety of branches and with larger samples. Female teachers should be encouraged to participate in in-service training sessions and workshops to improve their perceived selfefficacy for teaching with tablets.

\section{References}

1. Askar, P., \& Umay, A. Ilkogretim matematik ogretmenligi ogrencilerinin bilgisayarla ilgili oz-yeterlik algisi. Hacettepe Universitesi Egitim Fakultesi Dergisi, 21(21), (2001).

2. Bandura, A. Social foundations of thought and action: A social cognitive theory. Englewood Cliffs, NJ: Prentice-Hall, (1986).

3. Banoglu, K., Madenoglu, C., Uysal, S., \& Dede, A. FATIH projesine yonelik ogretmen goruslerinin incelenmesi (Eskisehir ili ornegi). Egitim Bilimleri Arastırmalari Dergisi, 4(1), 39-58, (2014).

4. Berkant, H. G. Ogretmen Adaylarinin Bilgisayara Yonelik Tutumlarinin ve OzYeterlik Algilarinin ve Bilgisayar Destekli Egitim Yapmaya Yonelik Tutumlarinin Bazı Degiskenler Acisindan Incelenmesi. The Journal of Instructional Technologies \&Teacher Education, 3, 11-22, (2013).

5. Ekici, S., \& Yilmaz, B. FATIH Projesi Uzerine Bir Degerlendirme. Turk Kutuphaneciligi, 27(2), 317-339, (2013).

6. Field, A. Discovering statistics using SPSS. Sage Publications, (2009).

7. Fraenkel, J. R., \& Wallen, N. E. How todesign and evaluate research in education (6th Ed.). Boston: Mac Graw-Hill, (2006). 
8. Gill, T. G. Using the tablet PC for instruction. Decision Sciences Journal of Innovative Education, 5(1), 183-190, (2007).

9. Horzum, M. B., Ozturk, E., Bektas, M., Gungoren, O. C., \& Cakir, O. Secondary school students tablet computer acceptance and readiness: A structural equation modelling. Education\&Science/Egitim ve Bilim, 39(176), (2014).

10. Ozkale, A., \& Koc, M. Tablet bilgisayarlar ve egitim ortamlarinda kullanimi: Bir alanyazin taramasi. SDU International Journal of Educational Studies, 1(1), 24-35, (2014).

11. Seferoglu, S. S., \& Akbiyik, C. Ilkogretim ogretmenlerinin bilgisayara yonelik ozyeterlik algıları uzerine bir calısma. Egitim Arastırmaları Dergisi, 19, 89-101, (2005). 